Acta vet. scand. $1987,28,65-71$.

From the Department of Internal Medicine, Small Animals and the Department of Microbiology and Immunology, Norwegian College of Veterinary Medicine, Oslo, Norway.

\title{
Occurrence of Autoantibodies against Thyroglobulin in Norwegian Dogs
}

\author{
By Ivar Vollset and Hans Jorgen Larsen
}

\begin{abstract}
Vollset, Ivar and Hans Jørgen Larsen: Occurrence of autoantibodies against thyroglobulin in Norwegian dogs. Acta vet. scand. 1987, 28, 65-71. - Serum samples from 45 hypothyroid dogs, 11 clinically healthy dogs and 31 dogs with various clinical endocrinopathies, seborrhoea and dermatitis were tested for thyroglobulin antibodies using the passive hemagglutination test. A chromic chloride (CCH)- and a glutaraldehyde $(\mathrm{GCH})$ method were used in the assay. Circulating antibody titer against thyroglobulin were observed in $34 \%$ and $24 \%$ of dogs with hypothyroidism by the $\mathrm{CCH}$ and the $\mathrm{GCH}$ method, respectively. Three of 12 dogs with seborrhoea had low titers (20 to 40 ) of thyroglobulin antibodies. Thyroglobulin antibodies were observed in 1 of 3 hypothyroid dogs with thyroid carcinoma. Clinically healthy dogs and dogs with certain other endocrinopathies (Addison's disease, Cushing's disease, Diabetes mellitus, Hyperestrogenism) and dermatitis were negative.

Though the $\mathrm{CCH}$ method detected thyroglobulin antibodies in more serum samples than the $\mathrm{GCH}$ method, the $\mathrm{GCH}$ method was considered more reliable in that the glutaraldehyde treated cells were more stable, both at room temperature and at $+4^{\circ} \mathrm{C}$.

passive hemagglutination; hypothyroidism; canine.
\end{abstract}

\section{Introduction}

Autoimmune thyroiditis and idiopathic follicular atrophy are the two main causes of primary hypothyroidism in dogs (Gosselin et al. 1982). Autoimmune thyroiditis, also called chronic lymphocytic thyroiditis, is comparable both histologically (Tucker 1962) and serologically (Mizejewski et al. 1971) to Hashimoto's thyroiditis in man. An autoimmune pathogenesis of chronic lymphocytic thyroiditis in dogs was further supported by the study of Gosselin et al. (1981). Their results indicated an antibody-dependent cell mediated cytotoxicity reaction as the main cause of cellular destruction in the thyroid gland.
Gosselin et al. (1980) detected thyroglobulin antibodies in 12 of 25 (48\%) hypothyroid dogs by the chromic chloride hemagglutination $(\mathrm{CCH})$ method, while only $6(24 \%)$ of the dogs showed detectable antibodies when the tanned cell hemagglutination method was used. The main disadvantage of the $\mathrm{CCH}$ method is, however, red cell instability, as discussed by Poston (1974), i.e. the red blood cells often hemolyses when stored. In addition both require freshly prepared thyroglobulin coated sheep red blood cells (SRBC). A glutaraldehyde hemagglutination $(\mathrm{GCH})$ method was therefore established (Vollset et al. 1987). 
The aim of this study was to assay thyroglobulin antibodies in Norwegian dogs. Further the method was compared with the $\mathrm{CCH}$ method. The frequency of thyroglobulin antibodies in serum from dogs with hypothyroidism and other clinical endocrinopathies, seborrhoea and dermatitis were investigated.

\section{Materials and methods}

\section{Animals and serum samples}

Serum samples were collected from healthy dogs, from dogs suffering from hypothyroidism and from dogs with skin diseases due to other clinical endocrinopathies, seborrhoea and dermatitis. Blood was drawn from the cephalic vein for serum collection, and stored in sterile tubes at $-20^{\circ} \mathrm{C}$. Radioimmuno assay (RIA) was used to determine thyroxine $\left(\mathrm{T}_{4}\right)$ concentration in serum ${ }^{\mathrm{a}}$. The thyroid-stimulating hormone (TSH) test was used to confirm the diagnosis of primary hypothyroidism. Blood samples were collected immediately before and $4 \mathrm{~h}$ after intravenous injection of $1 \mathrm{ml} / 5 \mathrm{~kg}$ body weight of Actyron $\left.{ }^{\circledR}\right), 2 \mathrm{IU} / \mathrm{ml}$.

\section{Preparation of thyroid antigens}

Canine thyroglobulin was isolated by chromatography as described by Vollset et al. (1987). The thyroglobulin was adjusted to a concentration of $1 \mathrm{mg} / \mathrm{ml}$ with phosphate buffered saline (PBS) and stored at $-20^{\circ} \mathrm{C}$ (Vollset et al. 1987).

Coating of sheep red blood cells (SRBC) with thyroglobulin

The chromic chloride method $(\mathrm{CCH})$ was performed as described by Gosselin et al. 1980 and Vollset et al. 1987.

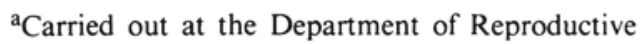
Physiology and Pathology, The Norwegian College of Veterinary Medicine.
The glutaraldehyde method $(\mathrm{GCH})$ was carried out as described by Vollset et al. 1987.

\section{Passive hemagglutination test (PHT)}

The PHT was performed in microtiter Vbottom plates with final RBC concentration of $0.33 \%$ (Vollset et al. 1987). Serum titer values $\geq 20$ were considered to constitute positive antithyroglobulin sera.

\section{Results}

Occurrence of autoantibodies in dogs with hypothyroidism

The presence of antibodies against thyroglobulin were investigated in 15 dogs with hypothyroidism (diagnosis based on clinical signs, thyroxine $\left(\mathrm{T}_{4}\right)$ measurements and thyroid stimulation tests). Antibodies were demonstrated in $8(57 \%)$ of $14^{*}$ dogs using the $\mathrm{CCH}$ method.

In contrast only 5 had positive serum titers when the GCH method was used (Table 1). The geometric mean serum titer value and $\mathrm{SD}$ (in positive samples) in the $\mathrm{CCH}$ test was $51.9 \pm 31.5$ compared to $52.8 \pm 20.3$ in the $\mathrm{GCH}$ test.

The average $T_{4}$ concentration in dogs with primary hypothyroidism was $5.7 \mathrm{nmol} / 1$ with SD 3.5 before TSH stimulation, and $8.7 \mathrm{nmol} / \mathrm{l}$ with SD 4.7 after TSH stimulation.

Occurrence of autoantibodies in dogs with low serum concentration of thyroxine $\left(T_{4}\right)$ Of 30 dogs with clinical symptoms of hypothyroidism and low serum $\mathrm{T}_{4}, 7(23 \%)$ had positive $\mathrm{CCH}$ test titer and $6(20 \%)$ a positive $\mathrm{GCH}$ test titer (Table 2). The average $\mathrm{T}_{4}$ concentration was $6.1 \mathrm{nmol} / \mathrm{l}$ with $\mathrm{SD}$ of 2.4 .

\footnotetext{
* One dog was not tested by the $\mathrm{CCH}$ method.
} 
Table 1. Serum titers of thyroglobulin antibodies and serum thyroxine $\left(\mathrm{T}_{4}\right)$ before and $4 \mathrm{~h}$ after injection of thyroid stimulating hormone (TSH) in 15 dogs with hypothyroidism.

\begin{tabular}{|c|c|c|c|c|}
\hline \multirow{2}{*}{ Dog no. } & \multicolumn{2}{|c|}{$\mathrm{T}_{4}(\mathrm{nmol} / \mathrm{l})$} & \multirow{2}{*}{$\begin{array}{l}\mathrm{CCH}^{\mathrm{a}} \\
\text { method }\end{array}$} & \multirow{2}{*}{$\begin{array}{l}\mathrm{GCH}^{\mathrm{b}} \\
\text { method }\end{array}$} \\
\hline & before & after TSH & & \\
\hline 1 & 6.0 & 7.4 & 0 & 0 \\
\hline 2 & 4.2 & 5.2 & $20^{*}$ & 0 \\
\hline 3 & 11.0 & 15.6 & 20 & 0 \\
\hline $4^{* *}$ & 6.8 & 9.0 & 0 & 0 \\
\hline 5 & 0.0 & 2.0 & nd & 40 \\
\hline 6 & 3.5 & 7.5 & 20 & 0 \\
\hline $7 * * *$ & 1.1 & 1.1 & 640 & 160 \\
\hline 8 & 11.0 & 12.8 & 0 & 0 \\
\hline 9 & 4.4 & 10.4 & 160 & 80 \\
\hline 10 & 6.8 & 9.2 & 40 & 20 \\
\hline 11 & 4.3 & 7.1 & 0 & 0 \\
\hline 12 & 0.7 & 3.3 & 40 & 40 \\
\hline 13 & 6.0 & 8.4 & 40 & 0 \\
\hline $14^{* * *}$ & 11.0 & 18.0 & 0 & 0 \\
\hline 15 & 8.0 & 14.2 & 0 & 0 \\
\hline \multicolumn{3}{|c|}{ Proportion seropositive: } & $8 / 14$ & $5 / 15$ \\
\hline \multicolumn{5}{|c|}{$\begin{array}{l}\text { a CCH: Chromic chloride hemagglutination } \\
\text { test } \\
\text { b GCH: Glutaraldehyde hemagglutination test } \\
\text { * Titer value expressed as inverse titer value } \\
\text { ** Thyroid atrophy } \\
\text { *** Thyroid carcinoma } \\
\text { nd Not done }\end{array}$} \\
\hline
\end{tabular}

Summation of data in Tables 1 and 2 shows that 15 (34\%) of 44 "hypothyroid" dogs had a positive $\mathrm{CCH}$ test titer and $10(23 \%)$ a positive $\mathrm{GCH}$ titer.

Thyroxine ( $\left.\mathrm{T}_{4}\right)$ measurements, and $\mathrm{CCH}$ and $\mathrm{GCH}$ tests in dogs with clinical endocrinopathies, seborrhoea and dermatitis and in clinically healthy dogs

Thyroxine and thyroglobulin antibody titers were measured in 31 dogs with endocrinopathies (other than hypothyroidism), seborrhoea, or dermatitis and in 11 clinically
Table 2. Serum titers of thyroglobulin antibodies in 30 dogs with clinical symptoms of hypothyroidism and low values of thyroxine $\left(\mathrm{T}_{4}\right)$.

\begin{tabular}{lccc}
\hline Dog no. & $\begin{array}{c}\mathrm{T}_{4} \\
(\mathrm{nmol} / \mathrm{l})\end{array}$ & $\begin{array}{c}\mathrm{CCH}^{\mathrm{a}} \\
\text { method }\end{array}$ & $\begin{array}{c}\mathrm{GCH}^{\mathrm{b}} \\
\text { method }\end{array}$ \\
\hline 1 & 4.0 & 40 & 20 \\
2 & 2.0 & 40 & 0 \\
3 & 4.0 & 20 & 20 \\
4 & 4.6 & 160 & 20 \\
5 & 4.5 & 40 & 20 \\
6 & 5.5 & 0 & 40 \\
7 & 4.5 & 80 & 40 \\
8 & 2.0 & 20 & 0 \\
$9-30^{*}$ & $6.9 \pm 2.3$ (SD) & 0 & 0 \\
\hline \multicolumn{2}{l}{ Proportion positive: } & $7 / 30$ & $6 / 30$ \\
\hline
\end{tabular}

For key, see Table 1.

* One of the dogs had thyroid carcinoma SD Standard deviation.

healthy dogs (Table 3 ). Low $\mathrm{T}_{4}$ concentration was observed in 5 dogs with dermatitis (mean: $10.7 \mathrm{nmol} / \mathrm{l} \pm 3.3 \mathrm{nmol} / \mathrm{l}$ ) in the one dog with Cushing's disease (hyperadrenocorticism) $(6.6 \mathrm{nmol} / \mathrm{l})$ and in 2 of 4 dogs with diabetes mellitus (mean: $15.0 \mathrm{nmol} / \mathrm{l} \pm$ $6.1 \mathrm{nmol} / \mathrm{l})$. One of 8 dogs with seborrhoea sicca (CCH and $\mathrm{GCH}$ titer: 40$)$ and 2 of 4 dogs with seborrhoea oleosa $(\mathrm{CCH}$ and GCH titer: 40 and 20 respectively) had antibodies against thyroglobulin. None of the dogs with dermatitis, Addison's disease, $\mathrm{Cu}$ shing's disease, diabetes mellitus, or hyperestrogenism which were tested, nor any of the clinically healthy dogs showed evidence of circulating thyroglobulin antibodies detectable by the $\mathrm{CCH}$ or $\mathrm{GCH}$ tests (Table 3).

Sex, age and breed distribution in dogs with autoimmune thyroiditis

Thyroglobulin autoantibodies were found in 7 of 16 hypothyroid female dogs and in 10 of 29 male dogs. The hypothyroid dogs tested were from 2 to 12 years old, with a 


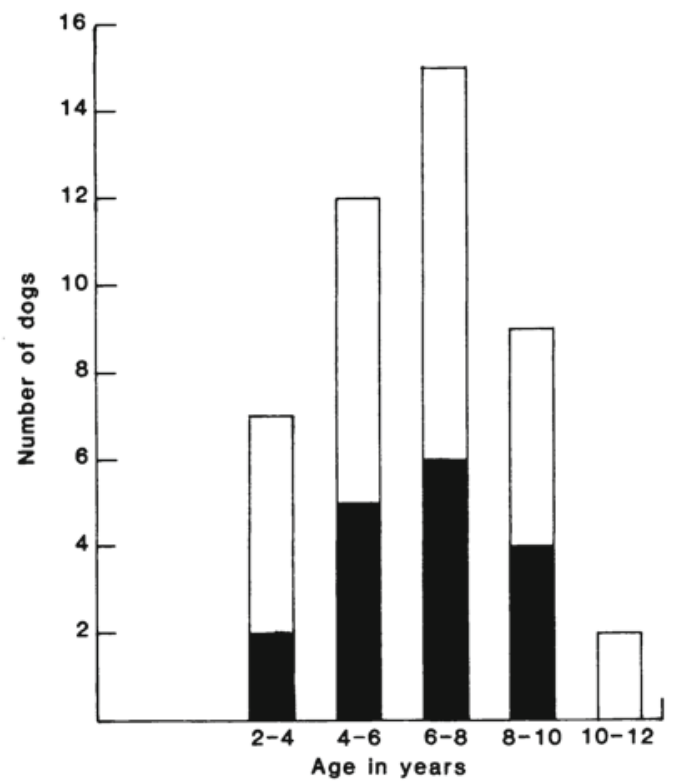

Figure 1. Age distribution of hypothyroid dogs. Open columns represent the total number of hypothyroid dogs. Black columns represent the number of hypothyroid dogs with thyroglobulin autoantibodies. mean age of 6.4 years and SD 2.2 years. The mean age of dogs with thyroglobulin autoantibodies was 6.4 years with SD 2.0 years (Fig. 1).

The hypothyroid dogs represented 21 different breeds in all. Gun dogs (English setters, retrievers, vorsthers and cocker spaniels) accounted for $44 \%$ and schnauzer dogs for $9 \%$. The remaining breeds were represented by 1 or 2 dogs each.

\section{Discussion}

This study shows that circulating thyroglobulin antibodies can be demonstrated in more than one third of dogs with hypothyroidism by the $\mathrm{CCH}$ test. The $\mathrm{CCH}$ test detected more hypothyroid dogs with circulating thyroglobulin antibodies than the GCH test, and gave a generally higher serum titer. If screening for thyroglobulin antibodies is done routinely in hypothyroid dogs, we would, however, recommend using frozen $\left(-196^{\circ} \mathrm{C}\right) \mathrm{SRBC}$ prepared by the GCH me-

Table 3. Serum thyroxine $\left(\mathrm{T}_{4}\right)$ and serum titers of thyroglobulin autoantibodies in 31 dogs with various clinical endocrinopathies, seborrhoea and dermatitis and in 11 clinically normal dogs.

\begin{tabular}{lcccc}
\hline & & & \multicolumn{2}{c}{$\begin{array}{c}\text { Proportion of dogs with } \\
\text { positive thyroglobulin } \\
\text { autoantibody titers }\end{array}$} \\
\cline { 4 - 5 } Group & No. of dogs & $\mathrm{T}_{4}$ (nmol/1) & $\mathrm{CCH}^{\mathrm{a}}$ & $\mathrm{GCH}^{\mathrm{b}}$ \\
\hline Dermatitis $^{\mathrm{c}}$ & 5 & $10.7 \pm 3.3(\mathrm{SD})$ & $0 / 5$ & $0 / 5$ \\
Dermatitis $^{\mathrm{d}}$ & 5 & $30.2 \pm 8.5(\mathrm{SD})$ & $0 / 5$ & $0 / 5$ \\
Addison's disease & 2 & $32.2 \pm 3.7(\mathrm{SD})$ & $0 / 2$ & $0 / 2$ \\
Cushing's disease & 1 & 6.6 & $0 / 1$ & $0 / 1$ \\
Diabetes mellitus & 4 & $15.0 \pm 6.1(\mathrm{SD})$ & $0 / 4$ & $0 / 4$ \\
Seborrhoea sicca & 8 & $28.5 \pm 6.7(\mathrm{SD})$ & $1 / 8$ & $1 / 8$ \\
Seborrhoea oleosa & 4 & $35.3 \pm 14.4(\mathrm{SD})$ & $2 / 4$ & $2 / 4$ \\
Hyperestrogenism & 2 & $28.5 \pm 5.5(\mathrm{SD})$ & $0 / 2$ & $0 / 2$ \\
Healthy dogs & 11 & $25.3 \pm 4.6(\mathrm{SD})$ & $0 / 11$ & $0 / 11$ \\
\hline
\end{tabular}

For key, see Table 1.

c Recent corticosteroid treatment

d No recent medication

SD Standard deviation 
thod in the passive hemagglutination test (Vollset et al. 1987).

Dogs with spontaneously occurring (primary) hypothyroidism showed decreased serum $\mathrm{T}_{4}$ concentration both before and after thyrotropin stimulation. A consistent absence of the usual increase in serum $\mathrm{T}_{4}$ concentration in response to thyrotropin stimulation was considered necessary to differentiate primary from secondary hypothyroidism. None of the hypothyroid dogs had been recently treated with corticosteroids or other drugs giving low $\mathrm{T}_{4}$ concentrations. The dogs presented in Table 1 had primary hypothyroidism (poor response to TSH stimulation). There were no significant differences in the mean $\mathrm{T}_{4}$ concentration in dogs presented in Tables 1 and 2. The proportion of dogs with thyroglobulin antibodies was, however, less among the dogs presented in Table 2 as compared to those presented in Table 1 . Though the number of dogs was different in the two groups, the presence of secondary or tertiary hypothyroidism in some of the dogs presented in Table 2 may provide an explanation for this observation.

In man, thyroglobulin antibodies detected by the PHT are found more frequently in females (Harboe \& Natvig 1982). In this study, no conclusive evidence of female predisposition was found.

Clinical symptoms of hypothyroidism only arise after about three quarters of the thyroid follicles are destroyed. The earliest histological evidence of autoimmune thyroiditis has been found in dogs of 7-8 months of age (Musser \& Graham 1968). The initial infiltration of lymfocytes in the thyroid gland occurs 2-3 years before clinical signs of hypothyroidism arise (Belshaw 1983). Belshaw (1983) has observed initial infiltration of lymfocytes in dogs as old as 4 years. In this study, the mean age of dogs with thyroglobulin antibodies was 6.4 years (SD 2.0 years) (Fig. 1). Most of the dogs had, however, shown clinical symptoms of hypothyroidism 3 months to 1 year prior to testing for thyroglobulin antibodies.

Thyroglobulin antibodies were observed in 1 of 3 dogs with thyroid carcinoma (Tables 1 and 2). In man, thyroglobulin antibodies may be present both in patients with thyroid carcinoma and in patients with autoimmune diseases such as systemic lupus erythematosus and autoimmune hypoadrenocorticism (Harboe \& Natvig 1982). In this study, thyroglobulin antibodies were not observed in endocrinopathies other than hypothyroidism (Table 3). Thyroglobulin antibodies were, however, observed in some dogs with seborrhoea (Table 3). These dogs had normal $\mathrm{T}_{4}$ levels, and the positive antibody titers possibly represent an early stage of autoimmune thyroiditis. Even though autoantibodies can be observed in relatively high titers in most patients with autoimmune diseases, it must be emphasized that this is also the case in some healthy control individuals. The frequency of positive antibody titers in healthy control individuals depends on the sensitivity of the test system used, in practice, the titer value selected to define the limit for a positive reaction. In man, thyroglobulin antibodies, detected by the PHT, are observed in $5-15 \%$ of control individuals (Harboe \& Natvig 1982). This is important to bear in mind when evaluating the PHT results, especially if more sensitive methods such as enzyme-linked immuno-sorbent assay (ELISA) or radio immuno assay (RIA) tests are used.

Decreased serum $\mathrm{T}_{4}$ concentrations are frequently associated with ongoing or recent administration of glucocorticosteroids, corticosteroid excess, phenobarbital and o,pDDD. This study showed that dogs with dermatitis which had recently been treated with corticosteroids, and also the one dog 
with Cushing's disease had low $\mathrm{T}_{4}$ concentrations (Table 3). Surprisingly, low $\mathrm{T}_{4}$ levels were observed in 2 of the 4 dogs with diabetes mellitus. On necropsy, adrenal tumors were found in both these dogs, the consequent high endogenous corticosteroid levels possibly explaining the low $\mathrm{T}_{4}$ concentrations.

Autoimmune thyroiditis must be considered an important cause of primary hypothyroidism in dogs. Histological investigation of a thyroid gland biopsy is a definite, though time-consuming procedure for the detection of autoimmune thyroiditis. Detection of antibodies against thyroglobulin is not in itself conclusive evidence of autoimmune thyroiditis, though positive antibody titer, together with absence of palpable abnormalities in the thyroid region, possibly constitutes a sufficient indication of autoimmune thyroiditis. Beierwaltes \& Nishiyama (1968) found autoimmune thyroiditis to be inherited polygenetically. Screening tests for the detection of autoantibodies to thyroid gland antigens may be of great value in the future in breeding programs to eliminate autoimmune thyroiditis, as well as for early detection of the disease, before clinical signs become manifest. In the light of the possible risk of immune complex deposition in other body organs mediated by thyroid antigens (Jordan et al. 1978), early diagnosis of autoimmune thyroiditis is important. Treatment with immune suppressive drugs may then be of value.

In man, autoimmune diseases of the thyroid gland have been shown to be associated with certain histocompatibility antigens. In the future, histocompatibility antigen typing may be the most suitable method for evaluating certain diseases in dogs.

\section{Acknowledgement}

This study was supported by a grant from the Norwegian Agricultural Research Council.

\section{References}

Beerwaltes $W H$, Nishiyama $R H$ : Dog thyroiditis: Occurrence and similarity to Hashimoto's struma. Endocrinology 1968, 83, 501-508.

Belshaw BA: Textbook of Vetefinary Internal Medicine, Vol. 2, 2nd ed. Ed. S. J. Ettinger. W. B. Saunders, Philadelphia 1983, p. 15921614.

Gosselin SJ, Capen CC, Martin SL, Krakowka $S$ : Biochemical and immunological investigations on hypothyroidism in dogs. Canad. J. comp. Med. 1980, 44, 158-168.

Gosselin, SJ, Capen CC, Martin SL, Krakowka $S$ : Induced lymphocytic thyroiditis in dogs. Effect of intrathyroidal injection of thyroid autoantibodies. Amer. J. vet. Res. 1981, 42, 1565 -1572 .

Gosselin SJ, Capen CC, Martin SL, Krakowka $S$ : Autoimmune lymphocytic thyroiditis in dogs. Vet. immunol. Immunparhol. 1982, 3, 185-201.

Harboe $M$, Natvig JB: Medicinsk immunologi. (engelsk oversættelse). 2nd ed. Stiftelsen Medicinsk Immunologi. Oslo, 1982, p. 213-219.

Jordan SC, Johnston WH, Bergstein JM: Immune complex glomerulonephritis mediated by thyroid antigens. Arch. Pathol. Lab. Med. 1978, 102, 530-533.

Mizejewski, GJ, Baron J, Poissant G: Immunologic investigations of naturally occuring canine thyroiditis. J. Immunol. 1971, 107, 1152 -1160 .

Musser, E, Graham WA: Familial occurrence of thyroiditis in purebred beagles. Lab. Anim. Care 1968, 18, 58-68.

Poston, RN: A buffered chromic chloride method of attaching antigens to red cells: Use in haemagglutination. J. Immunol. Meth. 1974, 5, 91-96. 
Tucker WE: Thyroiditis in a group of laboratory dogs. Amer. J. clin. Pathol. 1962, 38, 70-74.

Vollset I, Larsen HJ, Knavelsrud T: Passive hemagglutination for detection of autoantibodies against thyroglobulin in dogs. Acta vet. scand. 1987, 28, 117-119.

\section{Sammendrag}

Forekomst av autoantistoffer mot thyroglobulin hos norske hunder.

Serumprøver fra 45 hunder med hypothyroidisme, 11 klinisk friske hunder og 31 hunder med forskjellige kliniske endokrinopatier, seborre og dermatitt ble undersøkt med hensyn til thyroglobulin antistoffer, ved å bruke passiv hemagglutinasjons test.

En kromklorid $(\mathrm{CCH})$ metode og en glutaraldehyd $(\mathrm{GCH})$ metode ble brukt i undersøkelsen. Sir- kulerende antistoffer mot thyroglobulin ble påvist hos $34 \%$ og $24 \%$ av hundene med hypothyroidisme ved henholdsvis $\mathrm{CCH}$ og GCH metoden. Tre av 12 hunder med seborre hadde lave titre ( 20 og 40) av thyroglobulin antistoffer. Thyroglobulin antistoffer ble påvist hos 1 av 3 hypothyroide hunder med thyroideacarcinom.

Klinisk friske hunder og hunder med visse andre endokrinopatier (Addison's disease, Cushing's disease, Diabetes mellitus, Hyperøstrogenisme) og dermatitt var negative.

Selv om det ble påvist thyroglobulin antistoffer $\mathrm{i}$ flere serumprøver ved bruk av $\mathrm{CCH}$ metoden enn ved $\mathrm{GCH}$ metoden, ble GCH metoden betraktet som mer pålitelig siden glutaraldehyd behandlede celler var mer stabile både $\mathrm{i}$ rom temperatur og ved $+4^{\circ} \mathrm{C}$.

(Received November 3, 1986).

Reprints may be requested from: Ivar Vollset, Department of Internal Medicine, Small Animals, Norwegian College of Veterinary Medicine, P. O. Box 8146, Dep., N-0033 Oslo 1, Norway. 